\title{
BEYOND GEODESIGN: THE ARCHITECTURE OF SITESYNTHESIS
}

\author{
BIANCO Lino \\ Department of Architecture and Urban Design, Faculty for the Built Environment, University of Malta, Msida MSD 2080, Malta; \\ e-mail: lino.bianco@um.edu.mt
}

Received: 14.07.2017 / Accepted: 30.07.2017 / Revised: 31.10.2017 / Available online: 15.12.2017

DOI: 10.1515/jaes-2017-0008

KEY WORDS: landscape, geodesign, architecture, design, sensescapes, sitesynthesis

\begin{abstract}
:
This paper presents sustainable architecture as a function of sensory experience through time. Entitled sitesynthesis, this proposed approach forms the foundation of a holistic design methodology grounded physically in the geographical location of a given community and metaphysically in the spirit of place derived from sense experience. Sitesynthesis is made up of sitescapes which range from natural to cultural to social landscapes, themselves the product of the sensescapes through timescapes. The site is the place in geological, archaeological and historical time. The symbiotic relationship between the natural, cultural and social environs which sitesynthesis endeavours to attain is mutualistic rather than parasitic, a relationship from which society and the site both benefit rather than the former benefiting at the expense of the latter.
\end{abstract}

\section{INTRODUCTION}

"The main idea underlying the concept of geodesign, namely that the context of our geographic space conditions what and how we design (that is, how we adjust and adapt to our surroundings), has been with us since the beginning of time. ...

"The corollary is also true: what and how we design has the power to condition or change the context of our surroundings, that is, to change our geographic space" (Miller, 2012).

The value of geodesign is acknowledged in a recent publication on integrative theory approach to sustainable urban design (Aina et al, 2013). The importance of a holistic design approach integrating the brief of the client with the physical characteristics of a given site was a theme in the work of Richard Neutra (1954). In his seminal publication Design with Nature, Ian McHarg pioneered the idea of geodesign, although he never made use of the term, as an overlay of different environmental, cultural and social data (1969), an idea grounded in the theoretical work of Patrick Geddes. McHarg was a pioneer in adopting a multidisciplinary approach to environmental planning. He, most likely influenced by Warren Manning's work (Miller, 2012), paved the way for the essential concepts which were later developed into the GIS technology most notable through the work of Carl Steinitz (2012). Whilst McHarg was promoting his approach at the University of Pensnsylvania, Steinitz was contemporaneously developing geodesign at Harvard (Miller, 2012).

A widely accepted definition of sustainable development is the one included in the report Our Common Future chaired by the Norwegian Prime Minister at the time Gro Harlem Brundtland (Redclift, 2009; Petrovic et al., 2010; Petrovic et al., 2011a; Petrovic et al., 2011b; Radojicic et al, 2012; Sobczyk, 2014).
Known also as the Brundtland Commission, this report defines sustainable development as a "... development that meets the needs of the present without compromising the ability of future generations to meet their own needs" (World Commission of Environment and Development, 1987).

Since this publication, the term 'sustainable' has been used in several ways depending on the context in which it is expressed, academic, planning, business or environmental policy (Redclift, 2009). It calls for equilibrium between environmental protection and socio-economic sustainability. The concept is holistic notwithstanding the complexities and contradictions of the approach (Redclift, 1991; Redclift, 2009). Sustainability is multidimensional; environmental, economic and social aspects must all be considered and integrated (Radojicic et al, 2012); it goes beyond ecological and energy issues. It takes into account other considerations such as limiting environmental impacts of a given development and the preservation of natural and landscape values (Sobczyk, 2014). Seventeen sustainable development goals and hundred and sixty-nine targets were identified by The 2030 Agenda for Sustainable Development which was adopted in 2015 (United Nations, 2015).

The aim of this paper is to put forward the idea of architecture design grounded in the synthesis not only of the physical parameters of the site, dimensions that geodesign addresses, but also sense experience over time relating to the same location. The methodology was developed during the course of research for a conceptual redesign of a site at GHadira, Malta (Lino Bianco \& Associates, 2009). Thus this paper, after outlining the context in which the research developed, addresses sitesensitive characteristics with respect to time, the generator of sitescapes, and concludes by proposing a definition for the architecture of sitesynthesis. 


\section{MALTA: A CASE STUDY}

\subsection{Background}

Malta is the largest inhabited island in the Maltese Archipelago. In this European Union (EU) Member State which supports the highest population density, and pronounced natural and cultural heritage landscapes, the climate is typically Mediterranean with hot dry summers and mild humid winters. Its culture and vernacular architecture are a mixture of European and North African elements: the language is Semitic written in the Latin alphabet with a significant percentage of the vocabulary made up of romance words; its vernacular architecture and organic urban planning are typically of the Southern Mediterranean region with a Baroque parish church, the legacy of Europe, at the centre (Bianco, 2016a).

Since the early 1970 s a number of caravan and bungalow sites were set up at various locations on the island in close proximity to bays/sites accessible for swimming. Over the years these sites developed in an unregulated manner with no respect to planning legislation/s and environmental considerations. One such site is located at GHadira, established nearly four decades ago (Assocjjazzjoni tas-Sidien tal-Caravans u Bungalows, 2008) and which, at present, supports 236 units over a superficial area of circa $20,000 \mathrm{~m}^{2}$ (Figure 1).

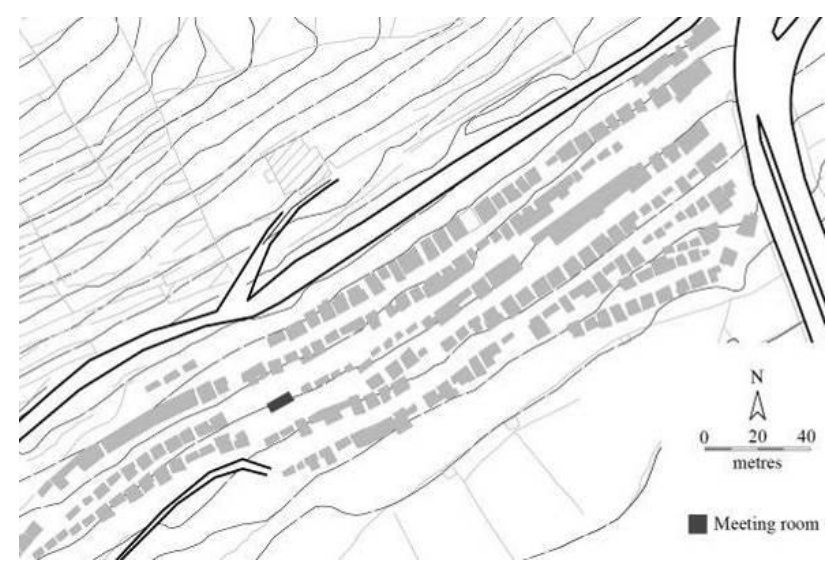

Figure 1. Existing layout of GHadira caravan and bungalow site, Malta (Based on Bianco, 2016b)

Aware of the environmental non-governmental organisations which became more effective post Malta's accession to the EU, the Association of Owners of Caravans and Bungalows at GHadira resolved in 2009 to commission a re-design of the entire settlement. The brief was to replace the poor quality intrusive units by environmentally sensitive ones which respect the characteristics of the site and the requirements of the occupants of these units.

Research related to the development of an architecture and urban concept for the redesign of GHadira in 2009 led to the development of a design which brings together the several parameters existing on site and which was done by an interdisciplinary team at Lino Bianco \& Associates. The aim was to develop a philosophy and a method which approach design holistically for a sustainable solution (Lino Bianco \& Associates, 2009) which goes beyond geodesign. It takes additional dimensions not addressed in the latter's approach, notable sense experience and time. The concept of sitesynthesis takes a systemic standpoint to address a practical problem, a theme central to Dragomirescu and Bianco (2017).

\subsection{Design philosophy}

The objectives identified by the design team to meet the brief of the client were to propose an architecture and urban design which (Lino Bianco \& Associates, 2009):

1. expresses the values of a particular society at a particular place and time;

2. creates an environment that includes identity and takes into consideration the geographical qualities of the site;

3. acknowledges the living complexity of a human settlement;

4. approaches architecture as a psycho-social science within a setting having its own particular geographical and cultural characteristics; and

5. creates an infrastructure which

i. is a reflection of the present settlement, and

ii. by taking into account the memories of the site and the development of the landscape in geological time, strengthens the accepted norms which the on-site community follows.

\subsection{Significance of this case study}

An aerial view of the GHadira caravan and bungalow site gives the impression of a floating leaf (Figure 3 ). This case study is an innovative design experiment in many ways. The participatory engagement of the residents at the caravan and bungalow site in the urban design proposal is documented in Bianco (2016b). This same publication includes a thorough description of the location and its immediate environs to a distance of $0.5 \mathrm{~km}$ radius, which environs incorporate a Foresta 2000 and a Natura 2000 sites just off its northern and southern periphery respectively.

One-to-one interviews with almost all the occupiers and the fieldwork undertaken within the study area published in Bianco (2016b) formed the basis for the architectural design team to undertake further studies which, at a meta level, resulted in the development of the architecture of sitesynthesis. The participatory design workshop with the residents ensured residential layouts that met the needs of the users. The existing substandard layouts were categorised and respective habitable prototypes developed.

\section{SITE-SENSITIVE, TIME-DEPENDENT DESIGN}

\subsection{Sensescapes: An overview}

A comprehensive reading about the developing research, including an extensive bibliography, in sensory studies is that of David Howes (2013). The number of senses identified by authors varies; some state between 10 and 33 (e.g. Howes, 2009), others between 22 and 33 (e.g. Smith, 2016), etc.

The traditional five exteroceptive senses are ophthalmoception, audioception, gustaoception, olfacoception and tactioception. Moving beyond the senses and landscape gives rise to sensescapes. As sensory studies can be broken down in terms of visual culture, auditory culture, taste culture, smell culture, and 
the culture of touch (Howes, 2013), sensory landscape (or sensescape) can be broken down into visualscape, $y_{1}$, soundscape, $y_{2}$, tastescape, $y_{3}$, odourscape, $y_{4}$, and tactilescape, $y_{5}$ (Table 2). Howes (2013) remarked that the "ostensibly visualist bias led to the concept of landscape being bracketed and replaced by the more neutral term 'sensescape"'. Making reference to Porteous (1990), he noted that sensescape was divided into a number of yscapes, namely, soundscape, smellscape, bodyscape and others.

Table 2. Sensescapes arising from the respective exteroceptive sense culture

\begin{tabular}{|l|l|c|c|}
\hline \multicolumn{1}{|c|}{ Senses } & Culture & Sensescape & \multicolumn{1}{|c}{} \\
\hline ophthalmoception & visual & visualscape & $y_{1}$ \\
\hline audioception & auditory & soundscape & $y_{2}$ \\
\hline gustaoception & taste & tastescape & $y_{3}$ \\
\hline olfacoception & smell & odourscape & $y_{4}$ \\
\hline tactioception & touch & tactilescape & $y_{5}$ \\
\hline
\end{tabular}

The hierarchy between the five senses changed along the course of history. Whilst nowadays the emphasis in the West is on sight, this was not the case, say, in sixteenth century France. At the time smells and sounds topped the list (Febvre, 1942). A study on each of these senses in nineteenth-century France was taken up by Alain Corbin in (1982) and (1994) respectively. During the Medieval era, it "was connected ... to the four elements in a way that reinforced and substantiated the primacy of seeing and the inferiority of touch" (Kern-Stähler and Scheuchzer, 2016).

More recent publications relating to sensory landscapes in general (e.g. Landry, 2012) and odourscapes in particular (e.g. Henshaw, 2013; Pennycook and Otsuji, 2015) are available.
Smith notes that sound, which supports a reading of the world essentially different from sight, had been neglected (Smith, 2004). He further argued, a point cited in Howes (2013), that nowadays not only is the bias in favour of the study of visual landscape but also of hypothetical models used in interpreting them. Sight has dominated today's culture such that it has suppressed the other senses, thus impoverishing the experience of architecture (Palasmaa, 1996).

The traditional senses are not independent from one another, a crucial point missed by Aristotle (Smith, 2013). The way these interact gives rise to varying perceptual experiences. Whereas in antiquity taste was read as a form of touch, nowadays it is more associated with smell (Howes, 2013). Such experiences are multimodal, frequently the synthesis of different sensory collections. For example, with respect to the experience of tasting, Smith argues that "what we call 'taste' is the result of the multisensory integration of touch, taste and smell" (Smith, 2013).

\subsection{Sitescapes: The foundation for an architecture of sitesynthesis}

The term sitesynthesis is derived from the words 'site' and 'synthesis`. Defining them is essential for a definition of sitesynthesis. The site may be defined as the place, not merely a location stated by geographical coordinates but an entity situated in geological, archaeological and historical time. It is the natural and human environs, both culturally and socially, symbiotically linked. The various landscapes generated by these environments present at a given site may be termed sitescapes. Synthesis is the assimilation of elements to form a whole. Thus sitesynthesis may be defined as the resultant integration of the physical and the metaphysical elements of a given site. It is rooted physically in the geographical location of a given society and metaphysically in the spirit of place (Lino Bianco \& Associates, 2009), the latter a concept developed by Christian Norberg-Schulz (1980).

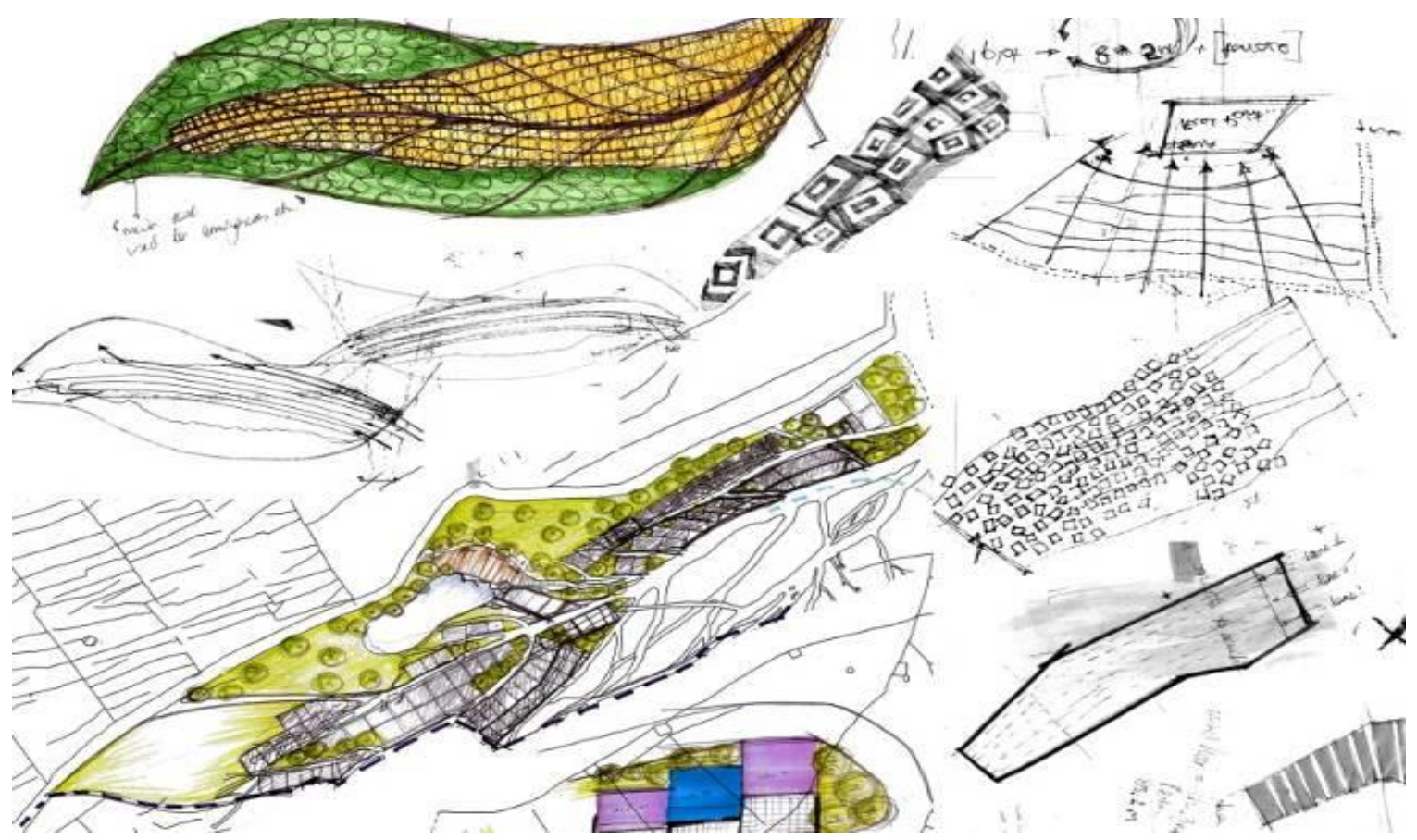

Figure 3. Preliminary concept sketches developed from existing site layout (Lino Bianco \& Associates, 2009) 


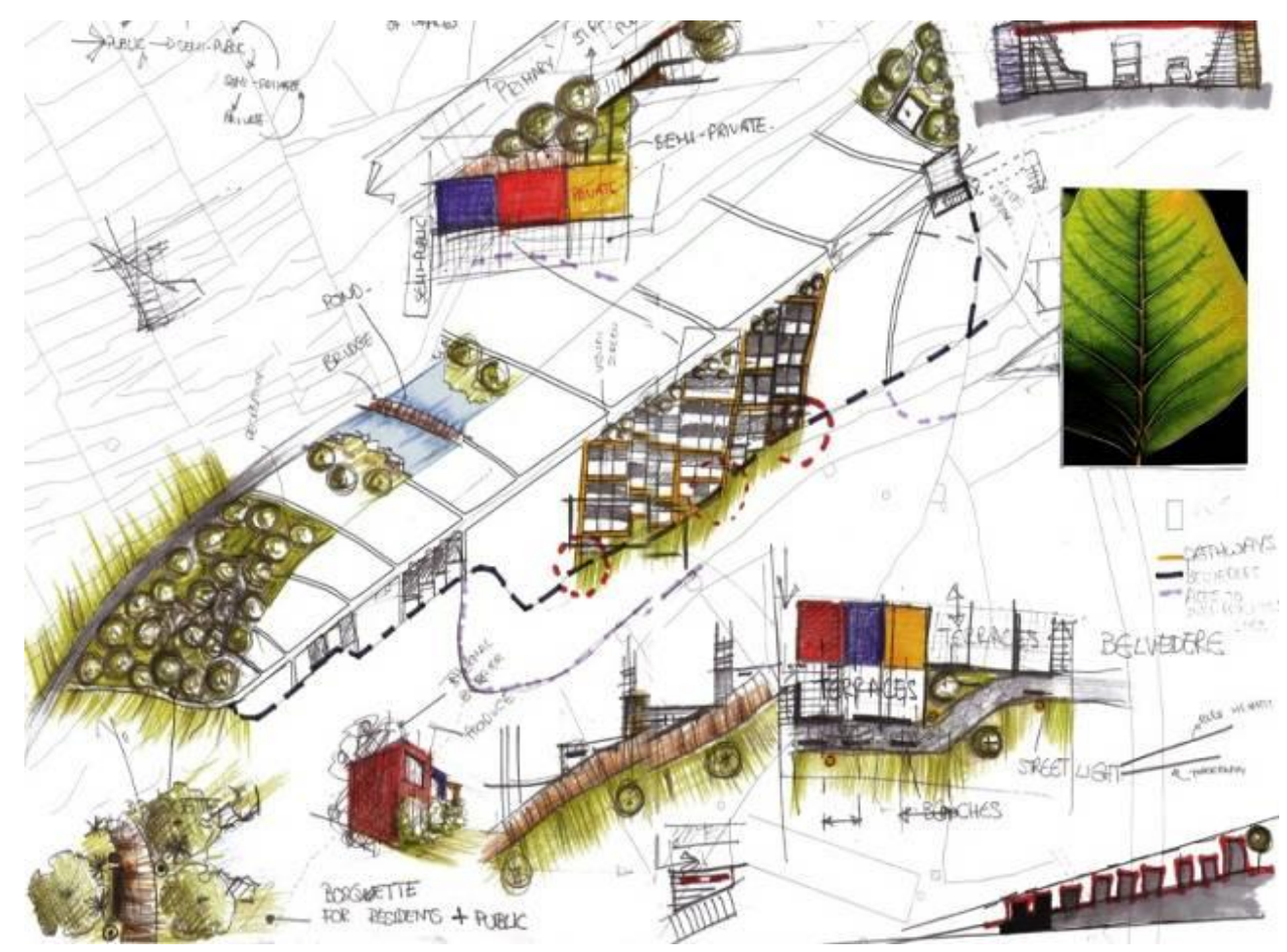

Figure 4. Concept sketches re the development of the masterplan inspired by the structure of a leaf (Lino Bianco \& Associates, 2009)

The symbiotic relationship which sitesynthesis attempts to attain is mutualistic rather than parasitic, a relationship from which society and the site both benefit rather than the former benefiting at the expense of the latter. It is an empirical approach rather than a poetical one as put forward by Kisho Kurokawa (1977, 1994). It is an existential reading of his "architecture of the age of life, based on the three key concepts of metabolism, metamorphosis and symbiosis" (Kurokawa, 1994).

Taking cognition of the traditional senses, the architecture of sitesynthesis (s) is made up of sitescapes which range from natural to cultural to social landscapes, themselves depending on the respective sensescapes, through timescapes: geological, $t_{1}$, archaeological, $t_{2}$, and historical, $t_{3}$. It is the integration of the physical and metaphysical characteristics of a given site over time. It constitutes the essence of a particular location in space and time. Thus $\mathbf{Y}$, the sense by environs matrix, and $\mathbf{t}$, the vector of timespaces, may be expressed mathematically as follows:

$$
\begin{gathered}
\mathbf{Y}:=\left(\begin{array}{ccc}
y_{1 n} & y_{1 c} & y_{1 s} \\
\vdots & \vdots & \vdots \\
y_{5 n} & y_{5 c} & y_{5 s}
\end{array}\right), \quad \mathbf{t}:=\left(\begin{array}{l}
t_{1} \\
t_{2} \\
t_{3}
\end{array}\right), \\
\mathbf{Y}:=g(\mathbf{t}), \\
\mathbf{s}:=f(\mathbf{Y}),
\end{gathered}
$$

Therefore $\quad \mathbf{s}:=f(g(\mathbf{t}))$ where: $\mathrm{y} 1 \mathrm{n} . . . \mathrm{y} 5 \mathrm{n}$ correspond to each sensescape with respect to the natural environs,

$\mathrm{y}_{1 \mathrm{c}} \ldots \mathrm{y}_{5 \mathrm{c}}$ correspond to each sensescape with respect to the cultural environs, and

$\mathrm{y}_{1 \mathrm{~s}} \ldots \mathrm{y}_{5 \mathrm{~s}}$ correspond to each sensescape with respect to the social environs.

\section{SITESYNTHESIS APPLIED}

\subsection{The case for GHadira}

The philosophy of sitesynthesis was applied to the politico-legal scenario in which the redesign of GHadira site was commissioned. Whilst acknowledging the significance of the geocultural and socio-economic environs, other dimensions addressed were thus political, legal and technical. These elements are fundamental to the concept of sustainable development (Pawlowski, 2009, as cited in Widomski et al, 2015).

At GHadira there is no cultural heritage and thus there is no dependence of $\mathbf{s}$ on $y_{1 \mathrm{c}}$ to $y_{5 \mathrm{c}}$. The natural gentle sloping terrain, recalling a process belonging to $t_{1}$, is mainly agrarian, a practice dating to the Neolithic Period, $t_{2}$, which has been used as such up to the present, $t_{3}$. The case study is located at the lower parts of this terrain and is surrounded by this natural heritage and thus $\mathbf{s}$ depends on the parameters $y_{1 \mathrm{n}}$ to $y_{5}$. Furthermore, it relates to a residential settlement and thus $y_{1 \mathrm{~s}}$ to $y_{5 \mathrm{~s}}$ apply.

The proposed masterplan fits the parameters of sitesynthesis and is analogous to a leaf structure (Figure 4). It has a stem, the midrib, as the main access route that will be used by vehicles 


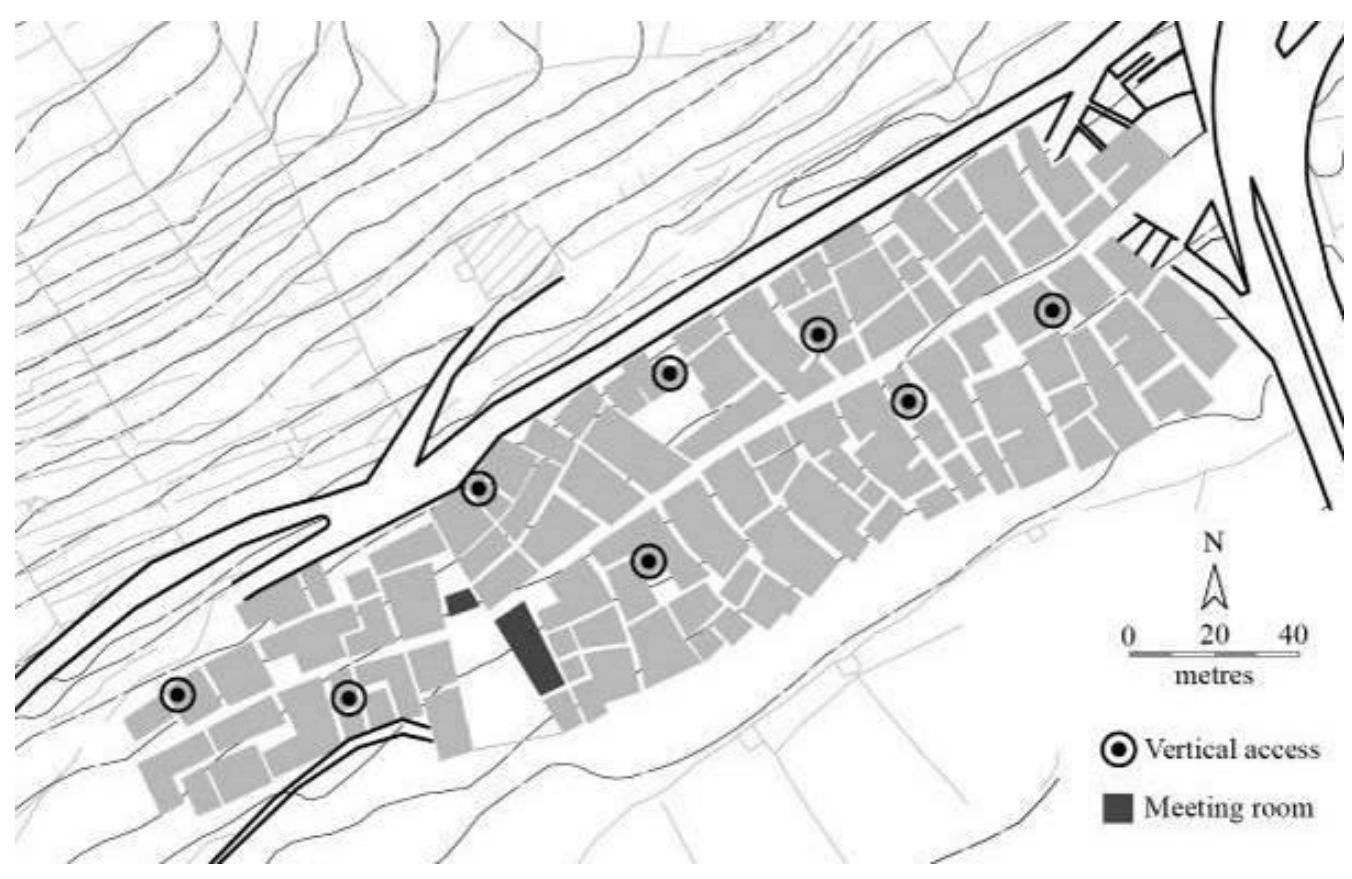

Figure 5. Proposed masterplan developed through sitesynthesis

for emergence purposes only, with sprouting narrow streets. The re-design consists of a number of units combined together in a cell-like structure.

The lateral veins became the footpaths to leave the settlement entirely pedestrian, and the residential units the lamina, designed in a staggered manner to resemble the flowing, terraced character of the site, thus respecting the evolution of the terrain through $t_{1}$ to $t_{3}$ (Figure 5). The orientation of the units followed the views and topography. An underground system for (i) waste collection points and (ii) parking was introduced. At present, the settlement is all at one level with a communal waste collection point close to the main entrance, a source of foul odour thus having a bearing on $y_{3 \mathrm{~s}}$ to $y_{5 \mathrm{~s}}$ if applying Smith (2013), and on-site unregulated car parking.

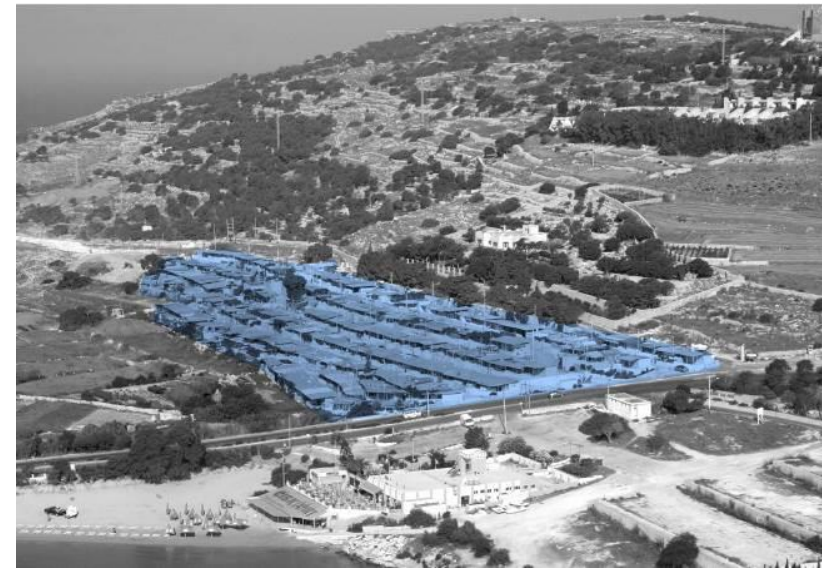

Figure 6. Aerial view of existing settlement (site indicated in blue; baseline photo furnished by the Assocjazzjoni tas-Sidien tal-Caravans u Bungalows, GHadira)
"The application of sitesynthesis led to a blueprint that, when implemented in practice, would have a favourable impact in terms of sustainable local development" (Dragomirescu and Bianco, 2017). Participatory engagement of the residents in the development of the urban planning proposal is itself a feature of sitesynthesis. Aerial views of the settlement as existing and as proposed are shown in Figures 6 and 7.

\subsection{Final comments}

Any natural organism undergoes a process of growth, a process of metamorphosis of the properties of the entity with time. The best examples are the growth of living cells and mineral formation. Other uses of the term 'growth' include metaphors such as 'a growing economy' or a 'growing city'.

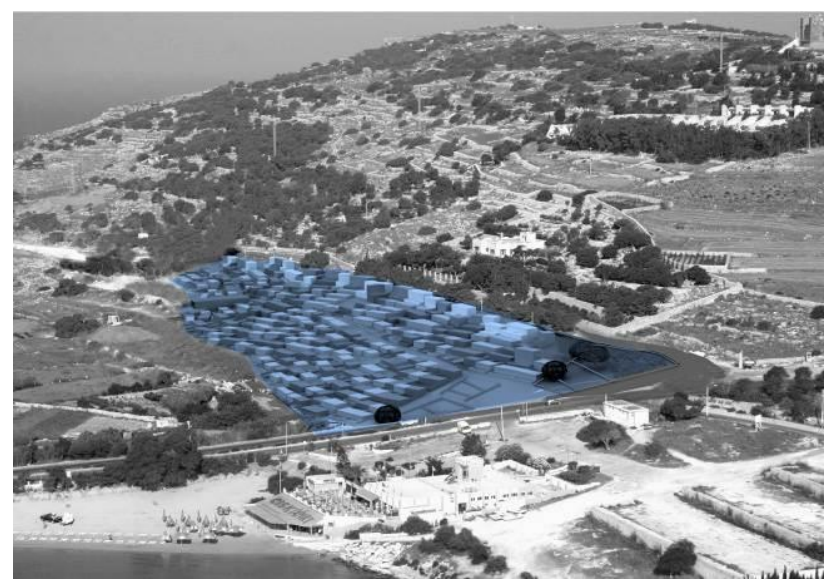

Figure 7. Aerial view of proposed settlement (site indicated in blue; baseline photo furnished by the Assocjazzjoni tas-Sidien tal-Caravans u Bungalows, GHadira) 


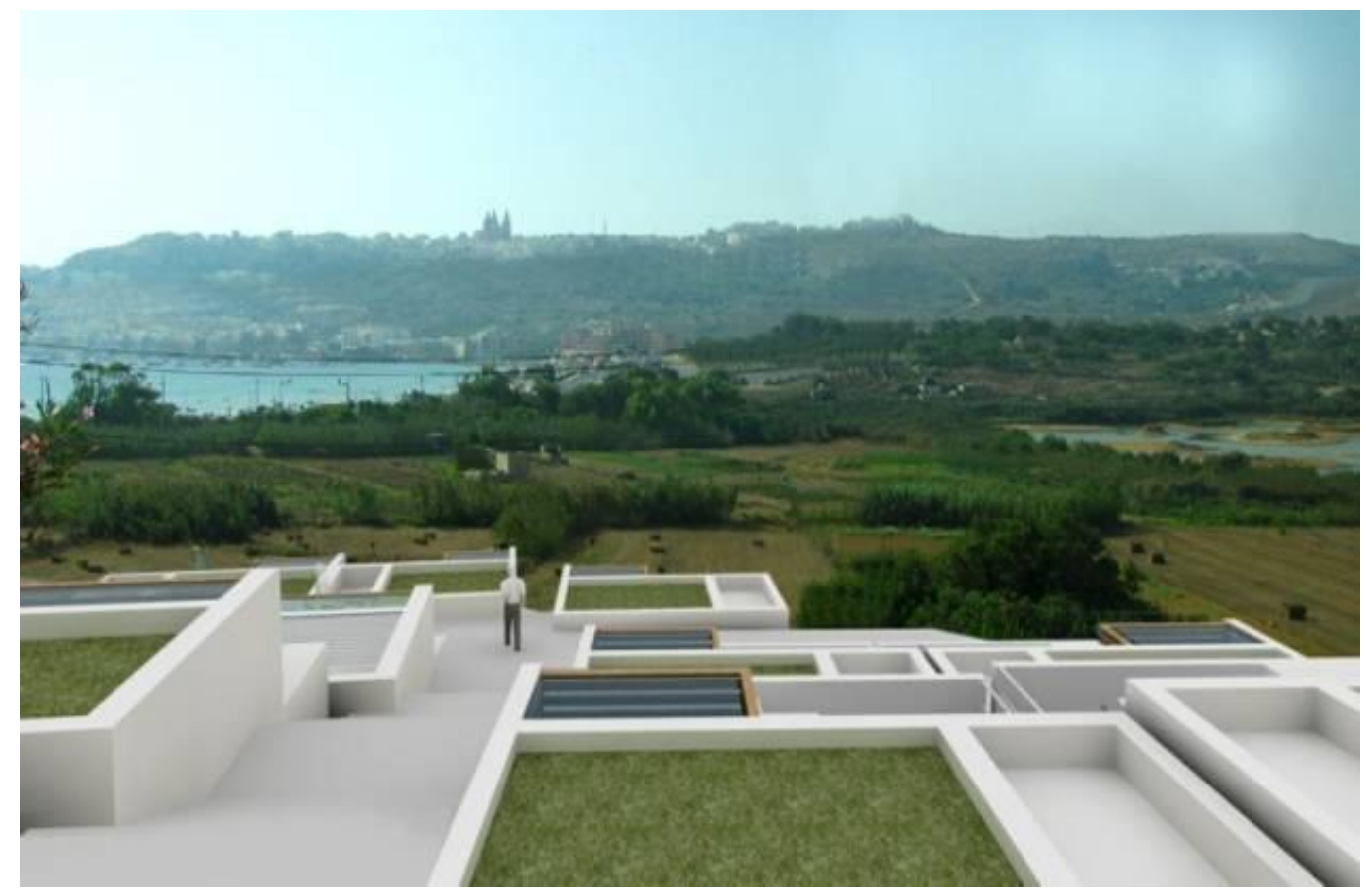

Figure 8. Bird's eye view of the proposed redevelopment of the site; the north-west access to the underground parking is visible (Lino Bianco \& Associates, 2009)

In the case of GHadira, visually the proposed individual units emerge from the natural landscape rather than impose on $y_{1}$. At the periphery of the site, the redesign of the settlement integrates into the natural terracing of the landscape (Figures 8 and 9). The experience of manoeuvring inside the urban spaces reflects the concept of growth with visual information being presented gradually, as opposed to a piazza that reveals the whole development at once, subsequently addressing the sensory landscapes $y_{2}$ to $y_{5}$. An organic hierarchy of transport routes is introduced: on plan to separate the public, semi-public, semi-private and private spaces, whilst in section to separate vehicles from pedestrians.

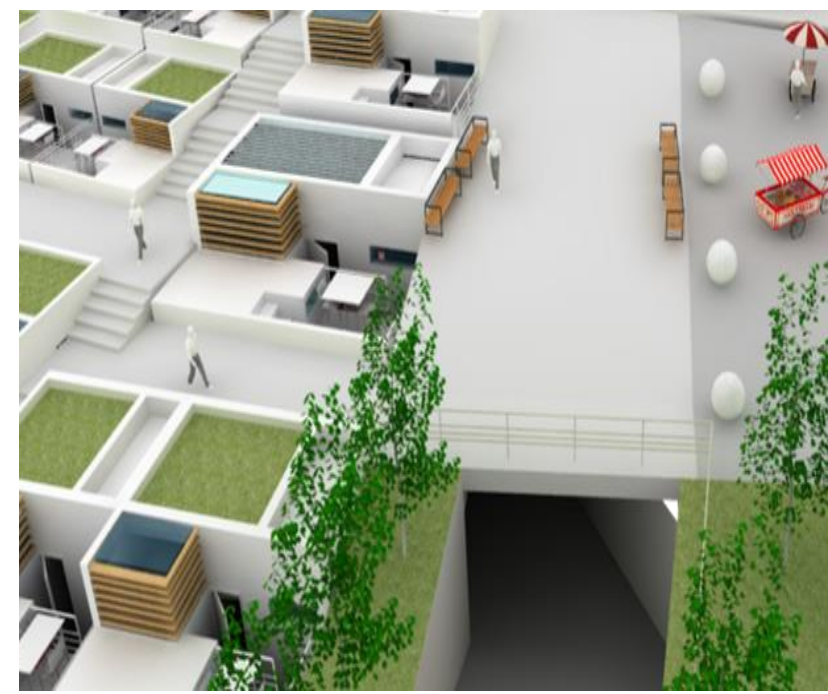

Figure 9. Artistic impression of a view of roof gardens towards the south-east (Lino Bianco \& Associates, 2009)

\section{CONCLUSION}

Understanding the present, respecting the natural and social environs of the community, the users, and the general public, and the application of technology, are fundamental to architecture and urban design. Such an approach respects and develops on the existing social infrastructure.

Grounded in both the collective physical and metaphysical characteristics of a given site, the architecture of sitesynthesis:

1. goes beyond critical regionalism and the post-modern philosophy of architecture and ecology. The phenomenological approach developed in the seminal publication of Norberg-Schulz (1965), Intentions in Architecture, is read in parallel with McHarg's work (1969);

2. is made up of sitescapes which are a function of sensory landscapes along timespaces; and

3. ensures that the resulting landscapes are sustainable.

Whilst acknowledging the symbiotic relationship between humanity and the built environment, a dimension that forms an intrinsic part of this design approach, sitesynthesis addresses other contexts that a given site offers, notably the development of natural, cultural and social environs along the ages. It does address the two key concepts included in the report of the Brundtland Commission (World Commission of Environment and Development, 1987):

"the concept of 'needs' ... and the idea of limitations imposed by the state of technology and social organization on the environment's ability to meet present and future needs". 


\section{REFERENCES}

Aina, Y.A., Al-Naser, A. and Garba, S.B., 2013. Towards an integrative theory approach to sustainable urban design in Saudi Arabia: The value of geodesign. Advances in Landscape Architecture, Özyavuz M. (ed.). InTech, Rijeka, 531-550, DOI: $10.5772 / 55888$.

Assoċjazzjoni tas-Sidien tal-Caravans u Bungalows, 2008. Caravan Site Ghadira: 30 Anniversarju 1978-2008. Malta, Mriehel, Caxton Printshop Ltd.

Bianco, L., 2016a. Rural and urban vernacular architecture of the Mediterranean: A source for contemporary, contextual, architectural design solutions. The 5th Electronic International Interdisciplinary Conference 2016, 8-12 August 2016, Slovakia, University of Zilina, 126-131.

Bianco, L., 2016b. Participatory engagement in urban design process: The case of an urban settlement in Malta, Spatium, 35, 71-78, DOI: 10.2298/SPAT1635071B.

Corbin, A., 1982. The Foul and the Fragrant: Odor and the French Social Imagination. Trans. Kochan, M.L., Porter, R., and Prendergast, C. Cambridge, Massachusetts, Harvard University Press, 1986.

Corbin, A., 1994. Village Bells: Sound and Meaning in the 19th-century French Countryside. New York, Columbia University Press, New York.

Dragomirescu H. and Bianco, L., 2017. Tackling sustainability from a systemic perspective: A contextualized approach, Problemy Ekorozwoju/Problems of Sustainable Development, 12(1), 31-39.

Febvre, L., 1942. The Problem of Unbelief in the Sixteenth Century: The Religion of Rabelais. Trans. Gottlieb, B. Cambridge, Massachusetts, Harvard University Press, 1982.

Henshaw, V., 2013. Urban Smellscapes: Understanding and designing city smell environments. New York, Routledge.

Howes, D. (Ed.), 2009. The Sixth Sense Reader. Oxford, Berg.

Howes, D., 2013. The Expanding Field of Sensory Studies, Centre for Sensory Studies. Montreal, Concordia University. http://www.sensorystudies.org/sensorial-investigations/theexpanding-field-of-sensory-studies/ (view at 14 October 2016).

Kern-Stähler, A. and Scheuchzer, K., 2016. Introduction. In: The Five Senses in Medieval and Early Modern England, ed. A. Kern-Stähler, B. Busse, and W. de Boer. Leiden/Boston, Brill, pp. 1-17.

Kurokawa, K., 1977. Metabolism in Architecture. Studio Vista, London.

Kurokawa, K., 1994. The Philosophy of Symbiosis. Academy Editions, London.

Landry, C., 2012. The Sensory Landscape of Cities. Gloucestershire, United Kingdom, Comedia.
Lino Bianco and Associates, 2009. GHadira: Upgrading of Caravan and Bungalow Site. Unpublished technical report, Hamrun, Malta.

Miller, W.R., 2012. Introducing Geodesign: The Concept. Redlands, Esri Press.

McHarg, I., 1969. Design with Nature. Cardell City, New York, Natural History Press.

Neutra, R., 1954. Survival through Design. New York, Oxford University Press.

Norberg-Schulz, C., 1965. Intentions in Architecture. Cambridge, MIT Press.

Norberg-Schulz, C., 1980. Genius Loci: towards a Phenomenology of Architecture. New York, Rizzoli, 1980.

Palasmaa, J., 1996. The Eyes of the Skin: Architecture and the Senses. London, Academy Editions.

Pawlowski, A., 2009. Rewolucja rozwoju zrównoważonego, Problemy Ekorozwoju/Problems of Sustainable Development, 4 (1), 65-76.

Pennycook, A. and Otsuji, E., 2015. Metrolingualism: Language in the city, Oxon and New York, Routledge.

Petrovic, N., Isljamovic, S. and Jeremic, V., 2010. Zero waste as a new concept for sustainable development, Management, 15(57), 39-45, UDC: 005.6:502.131.1; 628.4.

Petrovic, N., Isljamovic, S., Jeremic, V., Vuk, D. and Senegacnik, M., 2011a. Ecological footprint as indicator of students environmental awareness level at Faculties of Organizational Sciences, University of Belgrade and University of Maribor, Management, 16(58), 15-21.

Petrovic, N., Drakulic, M., Vujin, V., Drakulic, R. and Jeremic, V., 2011b. Climate changes and green information technologies, Management, 16(59), 35-43; UDC: 007:004Ё:551.5; 502.131.1:551.583.

Porteous, J.D., 1990. Landscapes of the Mind: Worlds of Sense and Metaphor, Toronto, University of Toronto Press.

Radojicic, Z., Isljamovic, S., Petrovic, N. and Jeremic, V., 2012. A novel approach to evaluating sustainable development, Problemy Ekorozwoju/Problems of Sustainable Development, 7(1), 81-85.

Redclift, M.R., 2009. Sustainable Development (1987-2005) an oxymoron comes of age, Problemy Ekorozowju/Problems of Sustainable Development, 4(1), 33-50.

Redclift, M.R., 1991. Sustainable Development: Exploring the contradictions. London, Routledge.

Smith, B.C., 2013. The Nature of Sensory Experience: the Case of Taste and Tasting. London, University of London, Institute of Philosophy, School of Advanced Study. http://www.phenomenologyandmind.eu/wp- 
content/uploads/2013/07/B.C.-Smith.pdf (view at 22 November 2016).

Smith, M.M. (Ed.), 2004. Hearing History: A Reader. Athens, University of Georgia Press.

Smith, B.C., 2016. We Have Far More Than Five Senses. https://www.youtube.com/watch?v=zWdfpwCghIw (view at 22 November 2016)

Sobczyk, W., 2004. Sustainable development of rural areas, Problemy Ekorozwoju/Problems of Sustainable Development, 9(1), 119-126.

Steinitz, C., 2012. A framework for Geodesign - changing geography by design. Redlands, Esri Press.

United Nations, 2015, Transforming our world: the 2030 Agenda for Sustainable Development (A/RES/70/1), https://sustaina bledevelopment.un.org/content/ documents/21252030\%20Agenda\%20

for\%20Sustainable\%20Developmen t\%20web.pdf (view at 9 May 2016)

Widomski, M. K., Glen, P., Lagod, G. and Jaromin-Gleń, K.M., 2015. Sustainable development of one of the poorest province of the European Union: Lublin Voivodeship, Poland -Attempt of assessment, Problemy Ekorozwoju/Problems of Sustainable Development, 10 (2), 137-149.

World Commission of Environment and Development, 1987. Our Common Future. New York, Oxford University Press.

\section{ACKNOWLEDGEMENTS}

The author appreciates the input of the inter-disciplinary team at the design studio Lino Bianco \& Associates whose insight and expertise were of great assistance for the research to be completed. Special mention goes to Professor Anton Buhagiar and Architects William Bondin and Stefania Buhagiar. Bondin's valuable comments proved instrumental during the critical discourse on the development of sitesynthesis. 